\title{
PENENTUAN JUMLAH UKURAN PAKAIAN OPTIMAL SEBAGAI RANCANGAN SISTEM UKURAN PAKAIAN ANAK LAKI-LAKI DI INDONESIA DENGAN ANALISIS KESEIMBANGAN DAN FUZZY C MEANS BERBASIS ARTIFICIAL BEE COLONY
}

\author{
Novenda Kartika Putrianto \\ Program Studi Teknik Industri Universitas Atma Jaya Yogyakarta \\ Jalan Babarsari 43 Yogyakarta \\ E-mail : novenda_kartika@mail.uajy.ac.id
}

\begin{abstract}
Size roll is one og the imprtant thing to develop sizing system. The more size, the more fitting with the consumer body shape so that customer satisfaction can be achieved from the accuracy of the size of clothing with body size. From the garment, the larger the number of sizes will impact on increases of setup cost or work stations. This research will develop a new sizing system approach which will analyze the trade off between production cost and maximum number of sizes. The meeting point between production cost and number of sizes is the optimum number of sizes that can meet the needs of consumers and and garments. Fuzzy c means based artificial (FCM ABC) algorithm used in this research to group several body sizes into several groups. The sample used 106 boys aged 8-10 years. This research contain several steps : 1. factor analysis, 2. determine optimum number of sizes, 3. Evaluation. Seven sizes were obtained and it used as number of sizes in sizing system. Aggregate loss qualify for validation so the proposed sizing system can be used to develop sizing system for shirts.
\end{abstract}

Keywords : sizing system, boys shirt, optimum number of sizes, factor analysis, fuzzy c means based artificial bee colony algorithm.

\section{Abstrak}

Jumlah ukuran adalah salah satu hal terpenting dalam merancang sistem ukuran pakaian. Semakin banyak jumlah ukuran pakaian maka akan semakin pas dengan bentuk tubuh konsumen sehingga kepuasan konsumen dapat tercapai dari sisi ketepatan ukuran pakaian dengan ukuran tubuh. Namun dari sisi produsen, semakin besar jumlah ukuran pakaian akan berdampak pada biaya setup ataupun penambahan lini produksi akibat penambahan variasi jumlah ukuran pakaian. Penelitian ini akan mengembangkan sistem ukuran pakaian baru dimana akan melihat titik titik seimbang antara biaya produksi dengan jumlah ukuran maksimal. Titik seimbang itu adalah jumlah ukuran optimal yang dapat memenuhi kebutuhan konsumen dan produsen secara bersama-sama. Metode FCM ABC akan digunakan untuk mengelompokkan ukuran tubuh menjadi beberapa kelompok. Sampel menggunakan 106 anak laki-laki umur 8-10 tahun. Penelitian terdiri dari tahapan yaitu Analisis faktor, Penentuan jumlah kelompok optimal, dan Evaluasi. Tujuh kelompok ukuran pakaian yang optimal dihasilkan. Nilai aggregate loss memenuhi syarat validasi sehingga dapat dikatakan pengembangan sistem ukuran baru dapat digunakan sebagai teknik untuk mendapatkan jumlah ukuran pakaian yang optimal.

Kata kunci : sistem ukuran, kemeja anak laki-laki, jumlah ukuran optimal, analisis faktor, fuzzy c means berbasis artificial bee colony.

\section{PENDAHULUAN}

Pakaian memainkan peran penting bagi kesehatan dan perkembangan anak-anak (Stonehouse, 2008). Pakaian untuk anak-anak perlu lebih fungsional untuk mengakomodasi pertumbuhan, memberikan kenyamanan dan meningkatkan kepercayaan diri mereka (Stonehouse, 2008; Kang et al., 2001). Norum (1996) menyebutkan pakaian tidak akan 
bermanfaat bagi anak-anak apabila pakaian tersebut tidak pas bagi mereka. Gautam (1995) juga menyatakan bahwa fitur kenyamanan pakaian bagi anak-anak adalah pakaian tidak terlalu ketat bagi mereka. Dengan demikian size roll (jumlah ukuran pakaian) memainkan peran penting dalam desain ukuran pakaian anak-anak.

Semakin banyak jumlah ukuran pakaian akan semakin pas dengan ukuran tubuh anak-anak. Semakin sedikit jumlah ukuran menyebabkan rentang konsumen yang menggunakan ukuran tersebut semakin lebar sehingga konsumen akan lebih longgar menggunakan ukuran pakaian tersebut (Gupta \& Zakaria, 2014). Jumlah ukuran pakaian yang banyak akan menguntungkan bagi konsumen karena ukuran pakaian lebih bervariasi dan lebih pas dengan ukuran tubuh konsumen (Tryfos, 1986). Namun jumlah ukuran pakaian yang banyak tersebut akan berdampak pada meningkatnya biaya produksi (Ashdown, 2007). Oleh karena itu perlu suatu cara untuk mendapatkan jumlah ukuran pakaian yang optimal yang dapat memenuhi kebutuhan produsen dan konsumen secara bersama-sama dimana mendapatkan nilai keseimbangan atau titik equilibrum dari biaya produksi dan jumlah ukuran pakaian.

Hsu et al. (2009), Esfandarani \& Shahrabi (2011) menggunakan expert judgement dan jumlah ukuran yang biasa digunakan di pasaran untuk menentukan jumlah ukuran pakaian yang akan digunakan dalam sizing system pakaian. Chung et al. (2007); Hsu (2009); Muslim et al. (2014) menggunakan 2-stage clustering dalam menentukan jumlah ukuran pakaian. Namun belum terdapat penelitian yang dapat menentukan jumlah ukuran pakaian yang optimal dilihat dari trade off antara biaya produksi dengan jumlah ukuran pakaian.

Sejak awal mula munculnya pakaian siap pakai (ready to wear) pada pertengahan tahun 1700an, muncul kebutuhan mengenai desain ukuran pakaian yang membagi ukuran tubuh kedalam beberapa kelompok ukuran [Beazley, 1997; Salusso, 1995). Hal ini tentunya membutuhkan metode yang sistematis dan scientific untuk mengukur dan mengklasifikasikan ukuran tubuh konsumen. Tryfos (1986), McCulloch et al. (1998) menggunakan metode optimisasi dalam pengembangan sizing system pakaian. Metode tersebut dapat menghasilkan fit yang optimal bagi konsumen namun prosesnya yang kompleks membuat metode tersebut sulit digunakan bagi produsen (Chung et al., 2007). Kemudian muncul data mining dalam pengembangan sizing system. Algoritma klastering non hirarki seperti fuzzy c-means (Hsu et al., 2009), kmeans (Esfandarani \& Shahrabi, 2011) dapat mengelompokkan ukuran tubuh populasi kedalam beberapa ukuran pakaian secara cepat dan mudah bila dibandingkan dengan integer programming dan non linier programming. Algoritma fuzzy c-means (FCM) memiliki performansi yang lebih baik dibandingkan dengan K-means. Namun penentuan centroid awal yang acak membuat algoritma FCM mudah terjebak kedalam solusi lokal optimum (Yunbin et al., 2014). Untuk mengatasi hal tersebut beberapa penelitian telah menerapkan algoritma optimisasi untuk mengatasi masalah inisialisasi parameter pada klustering(Setyohadi et.al, 2010).

Dalam pengotimasisaiannya, algoritma clustering banyak diperbaiki dengan berbagai pendekatan, misalnya pendekatan pembagian area ambigu cluster (Setyohadi et.al, 2015), ataupun Algoritma evolusioner seperti Algoritma Genetika (GA), Differential Evolution (DE), Particle Swarm Optimization (PSO), dan Artificial Bee Colony (ABC) diaplikasikan untuk memperbaiki kelemahan dari algoritma FCM (Karaboga \& Basturk, 2007; Halder et al., 2011; Maulik \& Saha, 2010; Niu \& Huang, 2011). Algoritma ABC terinspirasi dari perilaku cerdas dari lebah madu. Algoritma ABC ini memiliki kelebihan dalam kemudahan dalam implementasi, parameter kontrol yang lebih sedikit sehingga menyebabkan algoritma ini digunakan secara luas untuk menyelesaikan permasalahan optimisasi dan juga area data mining (Yunbin et al., 2014). Beberapa eksperimen juga menunjukkan algoritma $A B C$ menunjukkan performansi yang lebih baik dibandingkan DE, GA, dan PSO (Bao \& Zeng, 2009).

Penelitian ini bertujuan untuk mendapatkan jumlah ukuran yang optimal dengan mencari titik keseimbangan antara biaya produksi dengan jumlah ukuran pakaian. Dengan memperhatikan titik seimbang antara biaya produksi dan jumlah ukuran akan mendapatkan jumlah ukuran yang optimal dari sisi konsumen dan produsen. Algoritma kombinasi FCM ABC digunakan untuk mengelompokkan ukuran tubuh kedalam beberapa kelompok ukuran pakaian. 


\section{METODE PENELITIAN}

\subsection{RESPONDEN}

Sampel untuk penelitian ini adalah data antropometri dari 106 anak laki-laki berumur 8-10 tahun di kota Semarang, Jakarta, kabupaten Semarang dan kabupaten Boja. Pemilihan sampel dilakukan secara judgement sampling oleh peneliti dengan melihat tingkat ekonomi, asupan gizi dan aktivitas sehari-hari yang dilakukan oleh anak-anak.

\subsection{VARIABEL ANTROPOMETRI}

Variabel antropometri yang diukur berjumlah 14 dimana sesuai dengan variabel antropometri yang digunakan untuk pembuatan garmen anak-anak (Aldrich, 2009). Pengukuran antropometri dilakukan dengan menggunakan tape measure. Variabel antropometri yang diukur antara lain lingkar leher, lingkar dada, lingkar pinggang, lingkar lengan atas (sebelah kanan dan kiri), lingkar pergelangan tangan (sebelah kanan dan kiri), lebar punggung, panjang lengan pendek (sebelah kanan dan kiri), panjang lengan panjang (sebelah kanan dan kiri), scye depth, jarak titik tengkuk sampai pinggul (panjang baju), lebar bahu (sebelah kanan dan kiri).

\subsection{PENGOLAHAN DATA}

Pengolahan data pada penelitian ini terdiri dari beberapa langkah yaitu :

1. Analisis Faktor

Analisis faktor dilakukan untuk mendapatkan variabel baru yang digunakan untuk analisa kluster. Langkah-langkahnya adalah sebagai berikut :

a. Uji KMO. Apabila nilai $\mathrm{KMO} \geq 0,5$ maka dikatakan bahwa item-item yang dianalisis dapat dilakukan analisis faktor. Namun bila nilai $\mathrm{KMO}<0,5$ maka variabel dengan nilai korelasi terkecil pada matriks anti image dikeluarkan dari analisis dan lakukan uji KMO kembali.

b. Menentukan jumlah komponen yang terekstraksi dengan melihat eigenvalue> 1 .

c. Interprestasi komponen dapat dilakukan dengan mengetahui variabel-variabel yang membentuknya lalu memberi nama baru pada komponen yang sudah dipertahankan.

d. Memilih variabel yang diperlukan dalam pembuatan standar ukuran kemeja dengan melihat loading factor tertinggi.

2. Penentuan jumlah ukuran pakaian yang optimal.

Tahap ini adalah untuk mendapatkan jumlah ukuran pakaian yang optimal dengan melihat titik seimbang antara biaya produksi dengan jumlah ukuran pakaian maksimum. Proses pengelompokkan ukuran tubuh sampel kedalam beberapa kelompok ukuran menggunakan algoritma FCM ABC. Jumlah ukuran pakaian maksimum dilakukan dengan melihat presentase cover factor mencapai $80 \%$ populasi(Gupta \& Zakaria, 2014). Cover factor $80 \%$ menyatakan sistem ukuran pakaian semakin mendekati ukuran tubuh populasi dengan mengakomodasi minimal $80 \%$ populasi. Sedangkan biaya produksi dihitung dengan menghitung biaya yang dikeluarkan untuk memproduksi 1 buah ukuran sampai dengan jumlah ukuranmaksimum yang dihasilkan berdasarkan cover factor $80 \%$.

3. Algoritma FCM ABC.

Proses klastering dengan algoritma FCM $A B C$ adalah sebagai berikut :

Langkah 1. Inisialisasi semua parameter yang diperlukan yaitu jumlah populasi lebah, limit, dan jumlah iterasi. Penentuan nilai parameter pada penelitian ini menggunakan metode taguchi method.

Langkah 2. Fase inisialisasi.

a. Inisialisasi setiap sumber makanan sebagai $K$ random centroids

b. Membangkitkan inisial posisi populasi lebah menggunakan persamaan :

$z_{i, j}=z_{j_{\text {min }}}+\operatorname{rand}(0,1)\left(z_{j_{\text {max }}}-z_{j_{\text {min }}}\right)$

Dimana :

$z_{j_{\min }} \quad:$ batas bawah dari sumber posisi didalam dimensi $j$

$z_{j_{\max }} \quad$ : batas atas dari sumber posisi didalam dimensij

c. Menghitung membership matrix dengan menggunakan persamaan (5)

d. Menghitung nilai fitness dengan persamaan :

$$
\text { fit }_{i}=\left\{\begin{array}{c}
\frac{1}{1+F_{i}}, \text { if } F_{i} \geq 0 \\
1+\left|F_{i}\right|, \text { if } F_{i}<0
\end{array}\right.
$$

Dengan $F_{i}$ diperoleh dari persamaan : 
$\operatorname{SSE}\left(C_{1}, C_{2}, \ldots, C_{3}\right)=\sum_{k=1}^{n} \sum_{i=1}^{c} \mu_{i k}^{m} \cdot d\left(x_{k}, c_{i}\right)^{2}$

Dimana :
$c_{i} \quad$ : centroid dari klaster ke-i.
$m \quad$ : membership function $x_{k}$ pada centroidc $c_{i}$. Nilai default $m$ adalah 2.
$x_{k} \quad$ : nilai data ke- $k$ dari $d$-variabel data.
$n \quad$ : jumlah data item.
$\mu_{i k} \quad$ : level keanggotaan dari $x_{k}$ dalam klaster $i$.
$d\left(x_{k}, c_{i}\right)$ : jarak antara data $x_{k}$ ke centroid $c_{i}$.

Pusat klaster $c_{i}$ dan perubahan matriks partisi untuk memperbaiki membership function $x_{k}$ pada centroidc,dirumuskan pada persamaan (4) dan (5).

$$
\begin{aligned}
& \boldsymbol{c}_{i}=\frac{\sum_{k=1}^{n}\left(\left(\mu_{i k}\right)^{m} \cdot x_{k}\right)}{\sum_{k=1}^{n}\left(\mu_{i k}\right)^{m}} . \\
& \boldsymbol{\mu}_{i k}=\frac{1}{\sum_{j=1}^{c}\left(\frac{d_{i k}}{d_{j k}}\right)^{\frac{2}{m-1}}} .
\end{aligned}
$$

$\mu_{i k}$ merepresentasikan derajat keanggotaan dari $x_{k}$ ke klaster $c_{i}$, dimana semakin besar $\mu_{i k}$ maka semakin dekat $x_{k}$ ke centroid $c_{i \text {. }}$

Iterasi $=1$

Langkah 3. Fase employed bee

a. Untuk tiap employed bee, update posisi pencarian solusi oleh employed bee menggunakan persamaan :

$u_{i j}=z_{i, j}+\emptyset_{i, j}\left(z_{i, j}-z_{k, j}\right)$

Dimana :

$z_{i}:$ posisi employed bee ke-i

$z_{k}:$ tetangga employed bee dari $z_{i}$

$\emptyset$ : bilangan acak antara $[-1,1]$

$i \square\{1,2,3, \ldots, \mathrm{n}\}$

$k \square\{1,2,3, \ldots, \mathrm{n}\}$ dimana nilai dari $i \neq k$

$n$ : jumlah employed bee

$j \square\{1,2,3, \ldots, D\}$

$D$ : dimensi penyelesaian

b. Menghitung membership matrix dengan menggunakan persamaan (5).

c. Menghitung nilai fitness dengan persamaan (2).

d. Lakukan greedy selection untuk setiap posisi sumber makanan. Jika solusi baru hasilnya lebih baik dari sebelumnya, maka gantikan solusi lama dengan solusi baru. Jika tidak maka tambahkan counter trial (M) dengan 1.

e. Hitung probabilitas untuk setiap solusi baru employed bee dengan persamaan : $P_{i}=\frac{f\left(z_{i}\right)}{\sum_{j=1}^{S}\left(z_{j}\right)}$

Langkah $4 . \quad$ Fase onlooker bee

a. Untuk setiap onlooker bee, pilih solusi dari employed bee berdasarkan probabilitas $P_{i}$.

b. Untuk tiap onlooker bee, lakukan pencarian posisi solusi baru kembali dengan menggunakan persamaan (6)

c. Menghitung membership matrix menggunakan persamaan (5)

d. Menghitung nilai fitness dengan persamaan (2)

e. Lakukan greedy selection untuk setiap posisi sumber makanan. Jika solusi baru hasilnya lebih baik dari sebelumnya, maka gantikan solusi lama dengan solusi baru. Jika tidak maka tambahkan counter trial (M) dengan 1.

f. Hitung probabilitas untuk setiap solusi baru onlooker bee dengan persamaan (7). Langkah6. Fase scout bee

Hitung jumlah counter trial $(M)$ dan simpan jumlah $M$ maksimal untuk setiap bee yang tidak mengalami peningkatan solusi. Jika $M$ > limit maka tinggalkan solusi yang tidak mengalami peningkatan dan lakukan pencarian posisi solusi baru menggunakan persamaan (1). Namun jika $M<$ limit maka scout bee tetap memilih solusi sebelumnya. 
Langkah 7. Hafalkan solusi terbaik yang dicapai saat ini.

Langkah 8. Iterasi $=$ iterasi +1

Langkah 10. Lakukan sampai iterasi maksimal.

4. Evaluasi

Evaluasi dilakukan untuk mengetahui keakurasian hasil pengolahan data. Evaluasi pada penelitian ini dilakukan dengan mengevaluasi goodness of fit. Setiap ukuran yang dihasilkan dari penelitian ini disebut sebagai assigned size dan ukuran tubuh anak-anak disebut sebagai actual size. Goodness of fit dari suatu ukuran pakaian dievaluasi dengan menghitung jarak antara actual size dengan assigned size menggunakan aggregate loss, yaitu jarak euclidean antara 2 nilai. Agrregate loss $(d)$ dapat dihitung melalui persamaan:

$d=\sqrt{\sum_{i=1}^{n}\left(x_{i}-y_{i}\right)^{2}}$

Dimana $x$ adalah assigned size dan y adalah actual size.

Ideal value dari aggregate loss dihitung menggunakan jumlah variabel yang digunakan dalam membangun sizing system pakaian. Ideal value sizing system $(t)$ dapat dihitung dengan persamaan :

$t=\left(n^{1 / 2}\right) \cdot 2,54$

dimana $n$ adalah jumlah variabel yang digunakan dalam sizing system pakaian.

Jika nilai aggregate loss $(d)$ kurang dari ideal value $(t)$, maka ukuran pakaian yang dibangun dapat digunakan.

\section{HASIL DAN PEMBAHASAN}

\subsection{ANALISIS FAKTOR}

Nilai KMO pada tabel 1. menunjukkan angka 0,780 dimana nilai KMO tersebut lebih dari 0,5. Dengan demikian dapat dikatakan terdapat korelasi antar variabel sehingga dapat diolah menggunakan analisis faktor.

Tabel 1. Nilai KMO

\begin{tabular}{|c|c|}
\hline $\begin{array}{ll}\text { Kaiser-Meyer-Olkin Measure of Sampling Adequacy. } \\
\text { Bartlett's Test of } & \text { Approx. Chi-Square } \\
\text { Sphericity } & \text { df } \\
& \text { Sig. }\end{array}$ & $\begin{array}{r}.780 \\
3321.759 \\
120 \\
.000\end{array}$ \\
\hline
\end{tabular}

Selanjutnya menentukan jumlah faktor terekstrasi dengan melihat total eigenvalue lebih dari 1. Output eigenvalue dapat dilihat pada tabel 2. Pada tabel 2 dapat diketahui bahwa 4 komponen saja sudah dapat menjelaskan $84,766 \%$ variabel antropometri anak laki-laki. Faktor terekstraksi tersebut memiliki anggota sesuai tingkat korelasi yang dimiliki oleh tiap variabel terhadap faktor yang terbentuk. Anggota dari tiap faktor dapat dilihat pada tabel 3.

Tabel 2. Eigenvalue Data Variabel Antropometri Anak Laki-laki

\begin{tabular}{|c|r|r|r|}
\hline \multirow{2}{*}{ Komponen } & \multicolumn{3}{|c|}{ Data Laki-laki } \\
\cline { 2 - 4 } & Total Eigenvalue & \% Variasi & Kumulatif \% \\
\hline 1 & $\mathbf{6 , 7 3 1}$ & $\mathbf{4 2 , 0 6 6}$ & $\mathbf{4 2 , 0 6 6}$ \\
\hline 2 & $\mathbf{2 , 8 3 7}$ & $\mathbf{1 7 , 7 3 1}$ & $\mathbf{5 9 , 7 9 7}$ \\
\hline 3 & $\mathbf{2 , 5 0 8}$ & $\mathbf{1 5 , 6 7 6}$ & $\mathbf{7 5 , 4 7 3}$ \\
\hline 4 & $\mathbf{1 , 4 8 7}$ & $\mathbf{9 , 2 9 3}$ & $\mathbf{8 4 , 7 6 6}$ \\
\hline 5 & 0,850 & 5,316 & 90,082 \\
\hline 6 & 0,557 & 3,481 & 93,563 \\
\hline 7 & 0,392 & 2,448 & 96,010 \\
\hline 8 & 0,365 & 2,284 & 98,294 \\
\hline 9 & 0,135 & 0,846 & 99,140 \\
\hline 10 & 0,089 & 0,557 & 99,697 \\
\hline 11 & 0,016 & 0,098 & 99,795 \\
\hline 12 & 0,011 & 0,070 & 99,864 \\
\hline 13 & 0,011 & 0,069 & 99,933 \\
\hline 14 & 0,007 & 0,041 & 99,974 \\
\hline 15 & 0,003 & 0,019 & 99,993 \\
\hline
\end{tabular}




\begin{tabular}{|c|r|r|r|}
\hline \multirow{2}{*}{ Komponen } & \multicolumn{3}{|c|}{ Data Laki-laki } \\
\cline { 2 - 4 } & Total Eigenvalue & \% Variasi & \multicolumn{1}{|c|}{ Kumulatif \% } \\
\hline 16 & 0,001 & 0,007 & 100,000 \\
\hline
\end{tabular}

Tabel 3. Rotated Component Matrix

\begin{tabular}{clrrrr}
\hline \multirow{2}{*}{ No. Variabel } & & \multicolumn{3}{c}{ Komponen } \\
\cline { 3 - 5 } & & 1 & 2 & 3 & 4 \\
\hline 1 & Lingkar leher (NBG) & $\mathbf{0 , 5 9 3}$ & 0,343 & $-0,042$ & 0,168 \\
\hline 2 & Lingkar dada (C/BG) & $\mathbf{0 , 6 4 2}$ & 0,486 & 0,030 & 0,168 \\
\hline 3 & Lingkar pinggang (WG) & $\mathbf{0 , 8 0 6}$ & 0,231 & $-0,012$ & 0,241 \\
\hline 4 & lingkar lengan atas kiri (UAG-L) & $\mathbf{0 , 8 7 6}$ & 0,269 & $-0,064$ & $-0,030$ \\
\hline 5 & lingkar lengan atas kanan (UAG-R) & $\mathbf{0 , 8 7 2}$ & 0,266 & $-0,066$ & $-0,011$ \\
\hline 6 & Lingkar pergelangan tangan kiri (WG-L) & $\mathbf{0 , 8 7 4}$ & $-0,091$ & $-0,066$ & 0,085 \\
\hline 7 & Lingkar pergelangan tangan kanan (WG-R) & $\mathbf{0 , 8 6 7}$ & $-0,087$ & $-0,041$ & 0,058 \\
\hline 8 & Lebar punggung (ABW) & $-0,016$ & $-0,119$ & $\mathbf{0 , 8 4 5}$ & 0,013 \\
\hline 9 & Panjang bahu kiri (SL-L) & $-0,077$ & $-0,053$ & $\mathbf{0 , 9 6 6}$ & $-0,008$ \\
\hline 10 & Panjang bahu kanan (SL-R) & $-0,072$ & $-0,051$ & $\mathbf{0 , 9 6 6}$ & $-0,026$ \\
\hline 11 & Scye depth (SD) & 0,097 & 0,168 & $-0,023$ & $\mathbf{0 , 9 5 4}$ \\
\hline 12 & Panjang baju (NHL) & 0,199 & 0,255 & 0,010 & $\mathbf{0 , 9 0 9}$ \\
\hline 13 & Panjang lengan pendek sebelah kiri (AL-L) & 0,161 & $\mathbf{0 , 9 5 9}$ & $-0,088$ & 0,146 \\
\hline 14 & Panjang lengan pendek sebelah kanan (AL-R) & 0,166 & $\mathbf{0 , 9 6 0}$ & $-0,076$ & 0,130 \\
\hline 15 & Panjang lengan panjang sebelah kiri (UAL-L) & 0,158 & $\mathbf{0 , 9 6 3}$ & $-0,085$ & 0,140 \\
\hline 15 & Panjang lengan pendek sebelah & 0,155 & $\mathbf{0 , 9 6 3}$ & $-0,076$ & 0,142 \\
& kanan(UALR) & & & & \\
\hline
\end{tabular}

Variabel pada penelitian ini masih sama tetapi untuk lingkar lengan diwakilkan oleh variabel lingkar lengan sebelah kiri, lingkar pergelangan tangan diwakilkan oleh lingkar pergelangan tangan sebelah kiri, panjang lengan pendek diwakilkan oleh panjang lengan atas sebelah kiri, panjang lengan panjang diwakilkan oleh panjang lengan sebelah kiri, dan panjang bahu diwakilkan oleh panjang bahu sebelah kiri, sehingga dari 16 variabel direduksi menjadi 11 variabel. Kesebelas variabel yang digunakan adalah lingkar leher, lingkar dada, lingkar pinggang, lingkar lengan kiri, lingkar pergelangan tangan kiri, lebar bahu, panjang bahu sebelah kiri, scyedepth, panjang baju dari leher ke pinggul, panjang lengan atas sebelah kiri dan panjang lengan panjang sebelah kiri.

\subsection{PENENTUAN JUMLAH UKURAN PAKAIAN YANG OPTIMAL}

Semakin banyak jumlah kelompok ukuran pakaian maka semakin besar populasi yang dapat diakomodasi oleh sizing system. Pada tabel 4. dapat dilihat bahwa populasi yang mampu diakomodasi oleh 1 kelompok ukuran hanya sebesar 19\%. Hal tersebut terjadi karena 1 ukuran tersebut memiliki ukuran yang lebih longgar untuk populasi tersebut sehingga hanya mengakomodasi untuk anak-anak yang memiliki ukuran big size. Semakin banyak jumlah ukuran yang diproduksi maka akan semakin pas dengan ukuran tubuh anak-anak. Pada tabel 4. juga dapat disimpulkan bahwa dengan 14 kelompok ukuran pakaian dapat mengakomodasi $83 \%$ populasi, sehingga jumlah ukuran maksimal pada penelitian ini adalah sebanyak 14 ukuran.

Tabel 4. Cover Factor pada Setiap Kelompok Ukuran Pakaian

\begin{tabular}{|r|r|r|r|}
\hline $\begin{array}{c}\text { Jumlah } \\
\text { Kelompok } \\
\text { Ukuran }\end{array}$ & $\begin{array}{c}\text { Cover Factor } \\
\text { (dalam \%) }\end{array}$ & $\begin{array}{c}\text { Jumlah } \\
\text { Kelompok } \\
\text { Ukuran }\end{array}$ & $\begin{array}{c}\text { Cover Factor } \\
\text { (dalam \%) }\end{array}$ \\
\hline 1 & 19 & 8 & 67 \\
\hline 2 & 38 & 9 & 68 \\
\hline 3 & 46 & 10 & 69 \\
\hline 4 & 49 & 11 & 78 \\
\hline 5 & 56 & 12 & 77 \\
\hline 6 & 60 & 13 & 83 \\
\hline 7 & 61 & 14 & \\
\hline
\end{tabular}


Dengan jumlah 14 ukuran tersebut hanya dapat memenuhi keinginan konsumen dimana dengan jumlah ukuran yang banyak maka akan semakin pas dengan bentuk tubuh mereka. Namun dari sisi produsen hal tersebut akan meningkatkan biaya produksi seiring dengan penambahan lini produksi ataupun banyaknya biaya setup akibat perubahan pola ukuran pakaian dari ukuran satu ke yang lainnya. Untuk mendapatkan kebutuhan antara konsumen dan produsen secara bersama-sama maka perlu dilakukan analisis trade off. Analisis trade off ini dilakukan dengan melihat titik seimbang antara biaya produksi dengan loss of fit.

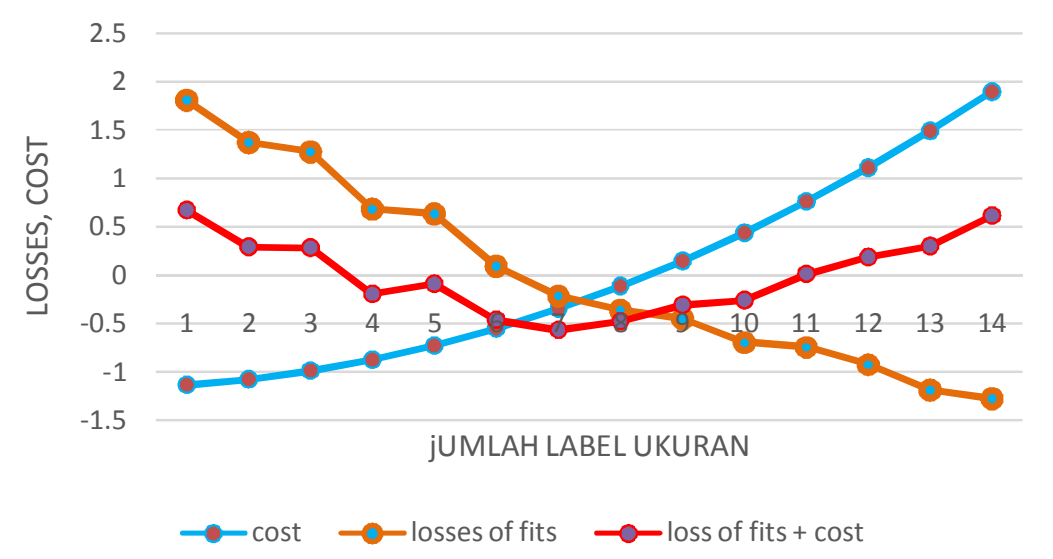

Gambar 1. grafik Hubungan Biaya Produksi dengan Loss of fit

Centroid hasil klaster dengan algoritma FCM ABC dapat dilihat pada tabel 5. Centroid tersebut nantinya akan digunakan sebagai ukuran pakaian. Loss of fit adalah kelonggaran pakaian atau jarak antara assigned size dengan actual size. Pada gambar 1. dapat dilihat bahwa titik seimbang terdapat di angka 7. Dengan demikian dapat disimpulkan bahwa jumlah ukuran yang optimal adalah sebesar 7 buah. Hal ini berbeda dengan jumlah label ukuran yang dikembangkan oleh SNI 7930 tahun 2013 dimana untuk untuk kemeja anak laki-laki umur 8-10 adalah sebanyak 3 buah. Jika dilihat pada tabel komparasi antara sizing system pada penelitian ini dengan sizing system SNI 7929 tahun 2013 (dapat dilihat pada tabel 6.), rata-rata aggregate loss pada sizing system pada penelitian ini adalah 3,76 dimana nilai tersebut lebih baik jika dibandingkan dengan milik SNI yaitu 7,41. Sizing system pada penelitian ini memiliki aggregat loss yang lebih kecil jika dibandingkan dengan SNI sehingga lebih pas dengan ukuran tubuh anak-anak namun juga dapat diterima oleh produsen.

Tabel 5. Centroid Hasil Klaster dengan FCM ABC

\begin{tabular}{|c|r|r|r|r|r|r|r|r|r|r|r|}
\hline Size & $\begin{array}{c}\text { Lingkar } \\
\text { leher }\end{array}$ & $\begin{array}{c}\text { Lingkar } \\
\text { dada }\end{array}$ & $\begin{array}{c}\text { Lingkar } \\
\text { perut }\end{array}$ & $\begin{array}{c}\text { Lingkar } \\
\text { lengan } \\
\text { atas }\end{array}$ & $\begin{array}{c}\text { Lingkar } \\
\text { pergelangan } \\
\text { tangan }\end{array}$ & $\begin{array}{c}\text { Lebar } \\
\text { punggung }\end{array}$ & $\begin{array}{c}\text { Lebar } \\
\text { bahu }\end{array}$ & $\begin{array}{c}\text { Syce } \\
\text { depth }\end{array}$ & $\begin{array}{c}\text { Panjang } \\
\text { baju }\end{array}$ & $\begin{array}{c}\text { Panjang } \\
\text { lengan } \\
\text { pendek }\end{array}$ & $\begin{array}{c}\text { Panjang } \\
\text { lengan } \\
\text { panjang }\end{array}$ \\
\hline 1 & 28,5 & 59,5 & 57,0 & 19,0 & 14,0 & 28,0 & 10,5 & 18,0 & 45,5 & 20,5 & 43,5 \\
\hline 2 & 29,5 & 63,0 & 59,5 & 20,0 & 14,0 & 27,5 & 10,5 & 19,0 & 48,5 & 22,5 & 48,0 \\
\hline 3 & 28,5 & 61,0 & 58,5 & 19,5 & 14,0 & 29,0 & 12,0 & 18,0 & 46,5 & 21,0 & 45,0 \\
\hline 4 & 30,0 & 64,5 & 61,0 & 21,5 & 15,5 & 28,5 & 11,0 & 19,5 & 50,0 & 22,0 & 48,0 \\
\hline 5 & 30,0 & 66,5 & 63,5 & 21,0 & 15,5 & 29,0 & 11,0 & 22,0 & 54,5 & 24,0 & 51,0 \\
\hline 6 & 29,5 & 64,0 & 61,0 & 21,0 & 15,0 & 28,0 & 11,0 & 18,0 & 47,0 & 22,5 & 48,5 \\
\hline 7 & 31,0 & 68,0 & 67,0 & 22,5 & 17,5 & 29,0 & 11,0 & 20,5 & 51,5 & 23,0 & 49,5 \\
\hline
\end{tabular}


Tabel 6. Perbandingan SizingSystem Penelitian dengan SNI

\begin{tabular}{ccc}
\hline & Size & Agg.loss \\
\hline \multirow{2}{*}{ Sistem } & 8 & 8,57 \\
\cline { 2 - 3 } Ukuran & 9 & 6,25 \\
\cline { 2 - 3 } SNI & 10 & - \\
\cline { 2 - 3 } & Rata-rata & 7,41 \\
\cline { 2 - 3 } & 1 & 4,23 \\
\cline { 2 - 3 } Sistem & 2 & 4,81 \\
\cline { 2 - 3 } Ukuran & 3 & 3,64 \\
\cline { 2 - 3 } Usulan & 4 & 4,91 \\
\cline { 2 - 3 } & \multicolumn{1}{c}{5} & 3,31 \\
\cline { 2 - 3 } & 7 & 2,92 \\
\cline { 2 - 3 } & Rata-rata & 2,54 \\
\hline
\end{tabular}

\subsection{EVALUASI}

Evaluasi pada penelitian ini dilakukan dengan membandingkan jarak euclidean atau aggregate loss antara assigned size dan actual size dengan ideal value. Pada tabel 7. dapat dilihat bahwa nilai aggregate loss untuk semua kelompok ukuran lebih kecil dari nilai ideal value. Dengan demikian dapat dikatakan sizing system pada penelitian ini dapat digunakan.

Tabel 7. Evaluasi Nilai Aggregate Loss dengan Ideal Value

\begin{tabular}{ccc}
\hline Size & Agg.loss & Agg.loss ideal \\
\hline 1 & 4,23 & 10,16 \\
\hline 2 & 4,81 & 10,16 \\
\hline 3 & 3,64 & 10,16 \\
\hline 4 & 4,91 & 10,16 \\
\hline 5 & 3,31 & 10,16 \\
\hline 6 & 2,92 & 10,16 \\
\hline 7 & 2,54 & 10,16 \\
\hline
\end{tabular}

\section{KESIMPULAN}

Sizing system pakaian pada penelitian ini bertujuan untuk mendapatkan jumlah ukuran yang optimal dimana melihat titik seimbang antara biaya produksi dengan loss of fit dari pakaian. Jumlah ukuran pakaian optimal diperoleh sebanyak 7 buah. Dengan evaluasi goodness of fits, sizing system pada penelitian ini dapat digunakan karena semua nilai aggregate loss di kelompok ukuran lebih kecil dari ideal value. Perbandingan dengan sizing system milik SNI juga menunjukkan hasil yang positif dimana rata-rata aggregate loss pada penelitian ini lebih kecil jika dibandingkan dengan rata-rata aggregate loss milik SNI. Kekurangan pada penelitian ini adalah masih terdapat ukuran yang overlap antar ukuran pakaian. Diperlukan perbaikan mengenai metode klastering untuk menghindari ukuran overlap antar ukuran. Selain itu, sampel pada penelitian ini terbatas pada anak laki-laki umur 8 sampai 10 tahun. Penelitian selanjutnya dapat menambah sampel anak laki-laki dari umur 3 sampai 12 tahun.

\section{DAFTAR PUSTAKA}

Aldrich, Winifred. 2009.Metric Pattern Cutting for Children's Wear and Babywear, $4^{\text {th }}$ Ed. John Wiley \& Sons Limited, United Kingdom.

Ashdown, S. P. 2007. Sizing in Clothing: Developing Effective Sizing Systems for Ready-toWear Clothing, $1^{\text {st }}$ Ed. Woodhead Publishing Limited, Cambridge.

Bao , J. Zeng. 2009. Comparison and analysis of the selection mechanism in the artificial bee colony algorithm. Ninth International Conference on. IEEE Vol. 1, pp. 411-416

Beazley, A. 1997. Size and Fit. Procedures in Undertaking a Survey of Body Measurements. Int Journal of Fashion Marketing and Management Vol 2, Issue 1, pp. 55-85

Chung, M. J., Lin, H. F., \& Wang, M. J. J. 2007.The Development of Sizing Systems for Taiwanese Elementary- and High-School Students.Int Journal of Industrial ErgonomicsVol. 37, Issue 8, pp. $707-716$ 
Esfandarani, M., \& Shahrabi, J. 2011.Developing a New Suit Sizing System Using Data Optimization Techniques.Int Journal of Clothing Science and TechnologyVol. 24, Issue 1, pp. 27-35

Gautam, S. 1995. Concept of General Consideration of Clothing for Preschool Children Among Rural Mothers of Palampur. Int Journal of Social Science Vol 11, pp. 253-254

Gupta, D.\& Zakaria, N. 2014.Anthropometry, Apparel Sizing and Design, $1^{\text {st }}$ Ed. Woodhead Publishing Limited, Cambridge.

Hsu, C. H. 2009.Developing Accurate Industrial Standards to Facilitate Production in Apparel Manufacturing Based on Anthropometric Data. Human Factors and Ergonomic in Manufacturing, 19(3), pp. $199-211$

Hsu, C. H., Lee, T. Y., \&Kuo, H. M. 2009.Mining the Body Features to Develop Sizing Systems to Improve Business Logistics and Marketing Using Fuzzy Clustering Data Mining. WSEAS Transactions on Computers, 8(7), pp. 1215-1224

Kang, Y., Choi, H.S., \& Do, W.H. A Study of the Apparel Sizing of Children's Wear. An Analysis of the size increments utilized in Children's Wear Based on Anthropometric Survey. Int Journal of Korean Home Economic Association English Edition, Vol. 2, pp. 96-110

Karaboga, D., \& Basturk, B. 2007.A powerful and efficient algorithm fornumerical function optimization: artificialbee colony $(A B C)$ algorithm. Int journal ofglobal optimization Vol. 39, issue 3 , pp. 459-471

Muslim, E., Nurtjahyo, B., Fileinti, N., Puspasari, M., Sibarani, T., \& Laksana, D. 2014.The Development of Standard Size for Clothes of Indonesian Boys Based on Anthropometric Data as a Reference to Formulate RSNI 0555:2013, Journal of ErgonomicsVol. 4, Issue 2, pp. $15-23$

Norum, P. 1995. Consumer Satisfaction with Shooping Experiences and Clothing Products in the Children's Wear Market. Int Journal of Consumer Studies and Home economics Vol. 1, pp. 331-347

Salluso, C.J. 1995. Discussant : Fit and Sizing. Proc of International Textile and Apparel Association, CA : Pasadena, pp. 97-97

Setyohadi, D. B., Bakar, A. A., \& Othman, Z. A. 2010. An improved rough clustering using discernibility based initial seed computation. In International Conference on Advanced Data Mining and Applications pp. 161-168. Springer, Berlin, Heidelberg.

Setyohadi, D. B., Bakar, A. A., \& Othman, Z. A. 2015. "Optimization overlap clustering based on the hybrid rough discernibility concept and rough K-Means." Intelligent Data Analysis 19.4 : 795-823

Stonehouse, Children's Clothing in Child Care, Australia National Children Accreditation Council Inc. (NCAC), 2008.

SNI 7930, 2013, Pakaian Jadi-Kain Tenun-Ukuran Kemeja Anak, Badan Standardisasi Nasional, Jakarta.

Tryfos, P. 1986.An integer programming approach to the apparel sizing problem. Int Journal of the Operational Research Society Vol. 37, Issue 10, pp. 1001-1006

Halder, A., Pramanik, S., Kar, A.2011. Dynamic ImageSegmentation using Fuzzy C-Means based GeneticAlgorithm.Int Journal of Computer Applications Vol. 28, issue 6, pp. 15-20

Maulik, U., \& Saha, I. 2010. Automatic fuzzy clustering usingmodified differential evolution for image classification.Geoscience and Remote Sensing IEEE, Vol. 48, issue 9, pp. 35033510

Niu, Q., \&Huang, X. 2011.An improved fuzzy C-meansclustering algorithm based on PSO. Journal ofSoftware Vol. 6, Issue 5, pp. 873-879

Yunbin, H., Yupeng, Xiao., Jing W., \& Song, L. 2014. International Conference on Software Intelligence Technologies and Application. 